\title{
Solidification/Stabilization Disposal of Medical Waste Incinerator Flyash Using Cement
}

\author{
*Agamuthu, P. \& Chitra, S.
}

Solid and Hazardous Wastes Laboratory, Institute of Biological Sciences, Faculty of Science, University of Malaya, 50603 Kuala Lumpur, Malaysia. *agamuthu@um.edu.my (corresponding author )

Received on $13^{\text {th }}$ May 2009, accepted in revised form $4^{\text {th }}$ November 2009.

\begin{abstract}
Medical wastes in Malaysia are incinerated with the ash disposed into landfills. We studied alternative treatments of medical waste incineration fly ash by solidification/stabilization (S/S) using three types of cement: OPC, MSC and GGBS. The effect of additives - activated carbon (Ac) and rice husk (Rh) on metal retention was also studied. Metal leaching was quantified using TCLP, JLT-13 and ANS 16.1 (modified). Compressibility strength was measured by ASTM (Compressive Strength of Hydraulic Cement Mortars). Ash contained high concentrations of $\mathrm{Al}, \mathrm{Ti}, \mathrm{Fe}, \mathrm{Zn}, \mathrm{Cr}, \mathrm{Fe}, \mathrm{Pb}$ and $\mathrm{Cu}$ and most of these elements leached heavily if not treated. TCLP and JLT-13 quantification showed all cement types prevented metal leaching. Solidification with Ac and Rh respectively further reduced leached metals by 10 and 20\%, resapectively. ANS 16.1 (modified) showed leach rates between $10^{-4}$ and $70 \mathrm{~cm} /$ day. Leachability Index rates exceeded 6.0, indicating low leaching. Compressive strength increased as cement loading and curing days increased. OPC showed higher metal retention efficiency and compressive strength. Estimated costs for S/S treatment are higher than current disposal costs. However, S/S products could be used as raw materials for construction.
\end{abstract}

(Keywords: Solidification/stabilization, Activated carbon, Cement, ANS, TCLP, JLT-13.)

\section{INTRODUCTION}

Fly ash is normally disposed into a landfill; however this could lead to surface and ground water contamination when the heavy metals in the ash migrate laterally. This became evident from the ground water monitoring conducted in 2002 by the Department of Environment, Malaysia, where water collected from monitoring wells from solid waste dumping sites exceeded the acceptable value for raw water quality under the National Guidelines for Drinking Water (1990). Heavy metals contained in the fly ash could cause detrimental environmental damage, especially bioaccumulation in the food chain. Hence disposal of these heavy metal laden ashes must be done carefully to prevent these metals from re-entering the environment in high levels, this being the reason why treating the fly ash prior to disposal into a landfill is gaining importance in Malaysia.

Disposal of the ash should be in accordance to Regulation 4 of the Environmental Quality (Scheduled Wastes) Regulations, 1989 where scheduled wastes must only be disposed of after proper treatment at prescribed premises and as far as is practicable be rendered innocuous (Environmental Quality Act, Malaysia, 1974). These ashes are to be disposed of in secure landfills and not into municipal landfills. Given these regulatory constraints, this paper examines flyash from clinical waste incineration:

a. An alternative effective treatment and disposal method by studying the solidification / stabilization of the flyash using cements (OPC, MSC, GGBS) and additives such as activated carbon and rice husk; and,

b. Determination and comparison of the leachability characteristics of the solidified ash, based on 3 leaching protocols, namely TCLP, ANS 16.1 and JLT-13.

\section{SOLIDIFICATION AND STABILIZATION (S/S) TECHNOLOGIES}

Solidification and stabilization $(\mathrm{S} / \mathrm{S})$ is a waste treatment technology that is gaining prominence to treat a variety of mixed organic and inorganic industrial wastes. This technology existed for 25 years having originally been used to treat low level radioactive waste (Pojasek, 1979, Subramanian and Mahalingam, 1980, Zamorani, 1994). The technique employs selected materials to alter the physical and chemical characteristics of the waste stream prior to disposal. It improves waste handling and physical characteristics, decreases surface area across which pollutants can transfer or leach, limits the solubility when exposed to leaching solutions and detoxifies the 
hazardous constituents (Wiles, 1987). A wide spectrum of wastes can be stabilized and solidified; radioactive or chemically hazardous wastes such as incinerator ash and other combustion ashes, bulk wastes from the power generation industries, sludge and filter cakes, contaminated soils, foundry sands, spent catalysts, tank bottoms, mine tailings and dredged sediments. The wastes may contain both inorganic and organic contaminants (Côté, 1989, Lambge et. al., 1997).

\section{Solidification and Stabilization Processes}

Solidification is that component of $\mathrm{S} / \mathrm{S}$ in which materials are added to the waste to produce a solid matrix. In addition to simple binding, it may also involve a chemical bonding between the toxic contaminant and an additive; also, when combined in right proportions, heavy metal fixation could occur by creating insoluble metal hydroxides. The binders used for this purpose also increase the strength and decrease the compressibility and permeability of the waste (LaGrega et al., 1994).

Stabilization is the other component of S/S where a physiochemical reaction is used to transform the contaminants to less mobile and less toxic forms to generate a chemically stable form (Means, 1995). The solidification and stabilization processes (S/S) are often combined to change the physical and chemical structure of the waste. This enables the contaminants in the waste to remain in the solidified matrix even though the matrix itself might deteriorate with time.

$\mathrm{S} / \mathrm{S}$ technology is recognized in the Resource Conservation and Recovery Act (RCRA) as a Best Demonstrated Available Technology (BDAT) for treating hazardous wastes (Biyani et al., 2001). According to United States Environmental Protection Agency (1989), solidification and stabilization of hazardous waste as a remediation technology is an important technology to be pursued. The common binder used for the S/S technology is cement. Cement solidification is suitable for inorganic wastes, especially those containing metals. Hydroxides of metals that are formed are less soluble as compared to the other ionic species of the metals. This method has been used to treat plating wastes that contain metals such as cadmium, chromium, copper, lead, nickel and zinc (USEPA, 1989). Cement S/S can also treat complex wastes that have PCBs, oil and oil sludges, vinyl chloride, ethylene dichloride, asbestos, sulfides and other materials. Once the cement-waste mixture reacts with water, the calcium silicate and calcium aluminate in the cement form hydrated silicate and aluminate compounds. The contaminants in the waste become entrapped within the pores of the porous gel structure, absorb on to the pores of the surfaces, react, or become incorporated into the gel matrix. At the same time calcium hydroxide is also created and this precipitates and becomes trapped in the pores. This creates a buffer capacity against acid attack of the matrix and a high pore water $\mathrm{pH}$ of 11 13 (Cheng and Bishop, 1996).

Addition of additives such as activated carbon causes sorption of chemical properties and heavy metals in the solidified matrix (Chan et al., 2000). This material is usually made from various plant tissues such as wood, sawdust, coconut shells, and walnut hulls or from coal, lignite or petroleum residues. The effectiveness of activated carbon in removing the materials is proportional to the high amount of surface area $\left(600-100 \mathrm{~m}^{2} / \mathrm{g}\right)$ of the activated carbon (Rhyner et al., 1995).

\section{Leaching Process and Mechanisms}

Leach test has been recognized as the primary and most widely used indicator evaluating the retention capacity of $\mathrm{S} / \mathrm{S}$ waste mass. Leach tests are accelerated examinations of waste stability and are usually aggressive in an attempt to compensate for their short duration and thus provides conservative assessments of leaching performance. Leaching solutions are usually distilled water, deionised water or dilute acids. The solutions are used to assess the extent of waste stabilization affected during processing and the capacity of binding agents to neutralize aggressive leachants (Zamorani, 1994). Cation exchange reactions can occur between the external solution and the cement binder. Anions in acidic solutions that form soluble calcium salts (such as calcium chloride, acetate and bicarbonate) will leach the calcium from the S/S solidified matrix. This will increase the permeability and the rate of further exchange reactions.

Leach tests available are classified as extraction tests, leach tests and column leach tests. Extraction tests such as Toxicity Characteristics Leaching Procedure (TCLP), Extraction Procedure (EP) Toxicity Tests and Japanese Leaching Test (JLT) involve agitation of ground/pulverized wastes in a leachant to achieve uniform mixing for a specific period. The leachant used may be acidic or neutral and usually has a leachant to waste ratio of 20:1. The leachant is analyzed for heavy metals and other constituents once the continuous mixing is stopped after a few hours (Chan, 1999). The TCLP allows leaching to be done at a lower $\mathrm{pH}$ than EP and JLT. This test will be able to provide the leaching concentrations of the metals from the solid. The release rates can be 
calculated as cumulative amount released over time to be compared with the total amount available for leaching (Cote et al., 1983).

A solidified waste is a porous solid and partially saturated with water so when exposed to a leachant, the chemical potential between the contaminant saturated pore water and the leachant causes diffusion of the contaminant from the solid surface to the leachant. Solubility of the contaminants is influenced by $\mathrm{pH}$ of the pore water and concentration gradient in the solid. Most cement-solidified matrix leachate is in a $\mathrm{pH}$ range of 10 - 11. Most heavy metals such as As, $\mathrm{Cr}, \mathrm{Ni}, \mathrm{Cu}, \mathrm{Zn}$ have minimum solubility at the $\mathrm{pH}$ range of 7.5 - 11, however, $\mathrm{Pb}$ shows higher solubility at both low and high $\mathrm{pH}$ but is generally insoluble at pH 7 - 11 (Chan et al., 2000). Leaching of heavy metals from cement-based waste is a complicated process. Studies have indicated that most leached cement samples have a surface skin. As leaching proceeds, the leached metals migrate through this surface skin before entering the leachate (Cheng et al., 1996).

Leaching of hazardous and trace elements from the solidified waste product is influenced by chemical, physical and biological factors (van der Sloot et al., 1989). Usually the physical and chemical factors are studied, as biological factors are quite difficult to quantify. The effect of $\mathrm{pH}$ on leaching mechanism is frequently studied to understand the leaching behaviour of metals from solidified wastes. Sorptionprecipitation and limited dissolution of the solid matrix, between an initial $\mathrm{pH}$ of 7.0 and 11.0 limits metal leaching. At a $\mathrm{pH}$ of 6.0 , metal leaching could be limited by diffusion through the solid matrix or slow dissolution of the silica matrix (Shively et al., 1992). Most heavy metals reach their lowest solubility at an approximate $\mathrm{pH}$ of 10 (Roy and Eaton, 1992).

\section{Unconfined Compressive Strength}

Unconfined compressive strength is measured to establish the cohesiveness of the materials. It also represents the effectiveness of the solidification and stabilization of the binder with the waste. The stronger the stabilized waste, the more effective the stabilization process. As such, the unconfined compressive strength is used to gauge the effectiveness of the stabilization. According to the current USEPA regulations, solidified and stabilized waste products must have a minimum of 28 daysunconfined compressive strength of 50 psi. This is important, as it has been established that a minimum strength of 50 psi or more is suitable strength for stabilized materials to support loads of pressures placed on it in the landfill.

\section{EXPERIMENTAL PROCEDURES}

\section{Collection of Ash Samples}

Ash samples were obtained from fly ash silos of the Radicare Clinical Waste Management Centre in Telok Panglima Garang, located in the state of Selangor in Central Peninsular Malaysia. The fly ash sample had to be sieved due to noticeable impurities in the form of unburned solids. Ash was stored in airtight containers to avoid contaminants and air moisture altering the chemical composition of the ashes.

\section{Binders and Additives Used}

Three types of cement with different chemical composition were used as binders (Table 1) Ordinary Portland Cement (OPC), Mascrete Cement (MSC) and Ground Granulated Blastfurnace Slag (GGBS). The effect of two additives, activated carbon (Ac) and pulverized rice husk ( $\mathrm{Rh}$ ), individually added to the cement mixture was also studied.

\section{Preparation of solidified waste matrix}

Cement and ash were mixed at various cement to ash ratios, ranging from $10 \%$ to $60 \%$ cement loadings, with corresponding ash loadings. The mixtures were homogenized with distilled water added to promote hydration and to obtain cement paste with good workability. The mixture was transferred to paper cups and left to cure for 72 hours (3 days) to determine the solidibility of the mixture within the time stipulated. It was found that $10 \%$ and $20 \%$ cement loadings did not solidify within 72 hours. So only $30 \%, 40 \% 50 \%$ and $60 \%$ cement loadings was used for mixing, casting and curing.

\section{Mixing, casting and curing}

Solidified waste matrices were prepared by homogenizing ash and cement with a mixer for 2 to 3 minutes. Water was added for hydration. When the mixture reached a cement sludge paste consistency, it was mixed at high speed for another 3 to 4 minutes. Next, the waste grout paste was transferred into 60 $\mathrm{ml}$ paper cups for the TCLP and JLT-13 specimens, while steel $(50 \mathrm{~mm} \times 50 \mathrm{~mm} \times 50 \mathrm{~mm})$ moulds were used for the unconfined compressive strength samples and cylindrical perspex moulds for the ANS 16.1 leaching matrixes. 
Table 1. Physical Properties and Chemical Composition of the Cements Used

\begin{tabular}{|c|c|c|c|}
\hline PHYSICAL PROPERTIES & OPC $^{1}$ & MSC $^{1}$ & GGBS $^{2}$ \\
\hline Fineness: Specific Surface $\left(\mathrm{m}^{2} / \mathrm{kg}\right)$ & 345.00 & 386.00 & 460.0 \\
\hline $\begin{array}{ll}\text { Setting time } & \text { Initial } \\
\text { (minutes) } & \text { Final }\end{array}$ & $\begin{array}{l}145.00 \\
195.00\end{array}$ & $\begin{array}{l}145.00 \\
195.00\end{array}$ & 189 \\
\hline Soundness: Expansion (mm) & 1.00 & Nil & 253 \\
\hline 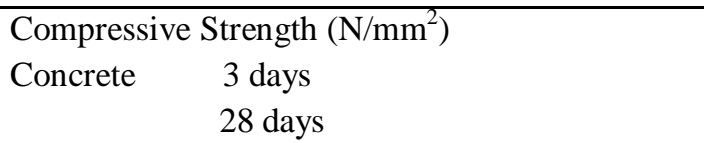 & $\begin{array}{l}19.50 \\
39.00\end{array}$ & $\begin{array}{l}17.50 \\
38.00\end{array}$ & $\begin{array}{l}11.5 \\
39.0\end{array}$ \\
\hline \multicolumn{4}{|c|}{ CHEMICAL PROPERTIES $(\mathrm{m} / \mathrm{m})$} \\
\hline \% Loss on Ignition & 1.70 & 2.00 & 2.7 \\
\hline \% Insoluble Residue & 0.17 & ND & 0.3 \\
\hline$\%$ Magnesia & 0.50 & 0.90 & 8.3 \\
\hline$\%$ Sulphuric Anhydride $\left(\mathrm{SO}_{3}\right)$ & 2.60 & 2.60 & 0.2 \\
\hline Lime Saturation Factor & 0.92 & ND & - \\
\hline$\%$ Chloride & 0.02 & ND & 0.02 \\
\hline$\% \mathrm{~K}_{2} \mathrm{O}$ & 0.62 & ND & - \\
\hline$\% \mathrm{Na}_{2} \mathrm{O}$ & 0.12 & ND & - \\
\hline$\% \mathrm{SiO}_{2}$ & 20.40 & ND & 31.5 \\
\hline$\% \mathrm{Al}_{2} \mathrm{O}_{3}$ & 6.10 & ND & 14.3 \\
\hline$\% \mathrm{Fe}_{2} \mathrm{O}_{3}$ & 3.90 & ND & 0.7 \\
\hline$\% \mathrm{CaO}$ & 63.50 & ND & 37.7 \\
\hline$\%$ Mangenese Oxide & - & - & 0.8 \\
\hline$\%$ Sulphide Sulphur & - & - & 0.8 \\
\hline$\%$ Free lime $(\mathrm{F} . \mathrm{CaO})$ & 2.90 & ND & ND \\
\hline $\begin{array}{l}\text { \% Proportion of Pulverized Power Plant Fly Ash } \\
\text { added as pozzolan to } \\
\text { OPC cement }\end{array}$ & - & 17.00 & - \\
\hline
\end{tabular}

ND-not detectable

All mixtures were levelled and compacted before the next layer was placed. The specimens were demoulded after 3 days and left to cure undisturbed for another 25 days at room temperature $\left(27-34^{\circ} \mathrm{C}\right)$ and relative humidity of $92 \%$. This was to simulate the curing condition as normally encountered in the landfill situation (Chan, 1999). The volume of the waste grout paste in the $60 \mathrm{ml}$ paper cups was recorded on the first and 28th day.
Three different trials were conducted with four different ash loadings of $70 \%, 60 \%, 50 \%$ and $40 \%$ corresponding to $30 \%, 40 \% 50 \%$ and $60 \%$ of cement (OPC / MSC / GGBS). The second and third trial incorporated activated carbon or rice husk at 4 to $7 \%$ with cement weight reduced accordingly and ash loading maintained. Cement and ash with activated carbon or rice husk was mixed in the same manner as cement and ash loading only (without activated carbon or rice husk). Table 2 summarizes the mix compositions. 
Table 2. Mixture Composition for Waste-Cement S/S Sample Matrixes

\begin{tabular}{|c|c|c|}
\hline \multicolumn{2}{|c|}{ Binding Agent } & Solid Waste Incinerator Ashes \\
\hline \multicolumn{1}{|c|}{ Type } & Amount (wt\%) & Amount (wt\%) \\
\hline \multirow{4}{*}{$\begin{array}{l}\text { Cement alone } \\
\text { (OPC / MSC/ GGBS) }\end{array}$} & 100 & - \\
\cline { 2 - 3 } & 60 & 40 \\
\cline { 2 - 3 } & 50 & 50 \\
\cline { 2 - 3 } & 40 & 60 \\
\cline { 2 - 3 } & 30 & 70 \\
\cline { 2 - 3 } Ac : Cement / Rh : Cement & 100 & - \\
\cline { 2 - 3 } & $4: 56$ & 40 \\
\cline { 2 - 3 } & $5: 45$ & 50 \\
\cline { 2 - 3 } & $6: 34$ & 60 \\
\hline
\end{tabular}

\section{Leaching Tests}

TCLP: Toxicity Characteristics Leaching

Procedure (USEPA, 1992)

The TCLP protocol USEPA method 1311 was carried out on the samples after 28 days of curing. An extraction buffer of acetic acid and sodium hydroxide of $\mathrm{pH} 2.88 \pm 0.05$ was prepared. The ratio of extraction liquid to crushed particles used was 20:1. The leachant was then analyzed for heavy metals in the extract. The results are expressed in terms of the percentage of the leachable fraction $(f)$ for each element. This shows the amount of a particular trace metal extracted relative to the amount in untreated ash, which actually shows the availability of metals for leaching from the solidified over a period of time.

\section{JLT-13: Japanese Leaching Test - Environment Agency Notification No. 13 (Mizutani et al., 2000)}

For this test, an extraction buffer of hydrochloric acid and sodium hydroxide of $\mathrm{pH} 6.00 \pm 0.05$ was prepared and used at a liquid-to-solid (L/S) ratio of 10:1. The buffer was added to the crushed waste matrixes and mechanically shaken for 6 hours in an incubator shaker continuously at $200 \mathrm{rpm}$. After 6 hours, the leachate samples were filtered and the $\mathrm{pH}$ and heavy metals in the leachant were analyzed in the same manner as for TCLP. The results were also expressed in terms of the percentage of the leachable fraction $(f)$ for each element.

\section{American Nuclear Society 16.1 (ANS 16.1, modified)}

This leaching procedure is a simplified and modified method from the American Nuclear Society for solidified low-level radioactive wastes in standard ANSI/ANS 16.1, which is conducted for 90 days. ANS 16.1 affords more information about the leaching rate of trace metals from the $\mathrm{S} / \mathrm{S}$ waste- cement matrix compared to TCLP and JLT-13. The leaching of the samples as performed for 28 days with leachate sampling occurring on the 1st, 3rd, 7th, 14th and 28th days. The trace metals in the leachate were analyzed using Inductively Coupled PlasmaAtomic Emission Spectroscopy. The results were recorded in terms of leaching rate $(l)$ and cumulative fraction leached $(C F L)$ relative to the total mass of the waste sample. From these results, the leachability index $(L i)$ was calculated. $L i$ is an indication of the effectiveness of the S/S method used for the control of the leaching of trace metals. The larger the $L i$ becomes, the lower the values of the diffusion of containments. The effective diffusion coefficient $(D)$ is a measure of the diffusibility of the heavy metals of concern in the S/S waste for each leaching interval.

\section{Unconfined Compressive Strength}

This test was carried out according to the American Standard Testing Material (ASTM) Test method for the Compressive Strength of Hydraulic Cement Mortars C190/C 109M-95. The strength measurements of the cubes were performed using a calibrated hand-operated hydraulic compression apparatus (model ELE) on the 7th, 14th and 28th days of curing. The total maximum loads were recorded at the point of fracture of the cubes.

\section{RESULTS AND DISCUSSIONS}

The modal diameter of the medical waste fly ash was $55.14 \mu \mathrm{m}$ while the mean diameter was $68.00 \mu \mathrm{m}$. The results of the acid digestion provided the absolute metals content of the ash sample. The untreated medical waste fly ash (MWFA) exhibited high contents of $\mathrm{Al}(28300 \mathrm{mg} / \mathrm{l}), \mathrm{Fe}(8040 \mathrm{mg} / \mathrm{l})$ and $\mathrm{Ti}(12600 \mathrm{mg} / \mathrm{l})$, however the highest metal content 
was $\mathrm{Zn}$ with $31100 \mathrm{mg} / \mathrm{l}$. Other heavy metals such as $\mathrm{Pb}, \mathrm{Cu}$ and $\mathrm{Hg}$ were also of concern as each revealed concentrations of $4870 \mathrm{mg} / \mathrm{l}, 1000 \mathrm{mg} / \mathrm{l}$ and 32601 $\mu \mathrm{g} / \mathrm{l}$ respectively. Heavy metals such as $\mathrm{Pb}, \mathrm{Zn}, \mathrm{Cd}$ and $\mathrm{Fe}$ are found in sharps, radioisotope shielding, chemotherapy waste, laboratory chemicals as well as pigment and additives found in the plastics. Plastics in the medical wastes originate from packaging materials/equipment. Mercury content in the ash is possibly from disposal of metallic material such as small equipment supplies containing $\mathrm{Hg}$ or paints and coatings of the material containing $\mathrm{Hg}$, discarded mercury thermometers, dental amalgams, and $\mathrm{Hg}$ batteries.

\section{TCLP Analysis Results}

The TCLP method showed that the solidification of MWFA using ordinary portland cement (OPC) alone inhibited all metals except for Fe and $\mathrm{Mn}$, however the percentage of leachable fraction was reduced to $1.6 \%$ for $\mathrm{Fe}$ (from $6.65 \mathrm{mg} / \mathrm{L}$ ) and $4.7 \%$ for $\mathrm{Mn}$ from $3.85 \mathrm{mg} / \mathrm{L}$ in the untreated ash, as the cement loading increased (Figure 1). The incorporation of activated carbon gradually reduced the leaching of heavy metals especially $\mathrm{Zn}$, from $24.81 \%$ (at $23 \%$ cement loading) to $0 \%$ (at $56 \%$ cement loading). Ac causes sorption of the chemical components and heavy metals into the solidified matrix (Chan et al., 2000). $\mathrm{Pb}$ however leached out for the rice husk / cement / fly ash ratio in a decreasing trend, from $0.84 \mathrm{mg} / \mathrm{L}$ to $0.01 \mathrm{mg} / \mathrm{L}$ as cement load increased (Figure 2). This is because the $\mathrm{pH}$ of the leachant samples was between 6.1-11.7, which is the zone of minimum solubility for most metal hydroxides exhibiting amphoteric behaviour, especially for $\mathrm{Pb}$. At the $70 \%$ MW ash loading, other metals were also detected in the leachate extract. The metals detected were $\mathrm{Zn}$ (25\%), Cd (2.8\%), Mn (28\%) and $\mathrm{Ni} \mathrm{(4.7 \% ),}$ however the percentage leaching out was reduced drastically and this was evident as the cement loading increased, the concentration of metals of concern leaching out into the leaching extract were below detection.

MWFA solidified with Mascrete (MSC) cement were also subjected to the TCLP test. The extract of the MSC leachate solution showed all metals of concern were below the TCLP limit test and the Malaysian Environmental Quality Act (EQA) 1974, Environmental Quality (Sewage and Industrial Effluents) Regulations 1979 limits except for $\mathrm{Cr}$ at $0.0624 \mathrm{mg} / \mathrm{l}$ which was slightly higher than the Malaysian Environmental Quality Act (EQA) 1974, Environmental Quality (Sewage and Industrial Effluents) Regulations 1979 of $0.05 \mathrm{mg} / \mathrm{l}$. The final
$\mathrm{pH}$ of the leaching extract was at 9.5, which shows high alkalinity MWFA when solidified with mascrete cement (MSC) alone and with rice husk (Rh) indicated that most of the metals were below detection levels for all the ash loading (70 - 40\%). However, the addition of Ac reduced the efficiency of immobilization of the metals and does not appear to stabilize $\mathrm{Zn}, \mathrm{Pb}, \mathrm{Cu}, \mathrm{Mn}$, and $\mathrm{Ni}$ from leaching out. The leaching concentrations of these metals were reduced to below the EQA limit as the cement load increased from $23 \%$ to $56 \%$ (Figure 3 ).

The solidification of all the ash with ground granulated blast slag (GGBS), it showed that most of the metals were found to reducing in the percentage of leachable fraction as the cement loading increased. However when Ac, was combined to the solidification, $\mathrm{Pb}$ was found to be increasing from 3.1 - $15.8 \%$ as the ash loading increased. The addition of $\mathrm{Rh}$ still had most metals leaching in the $70 \%$ and $60 \%$ ash load but in the $59 \%$ and $40 \%$ ash load, only $\mathrm{Pb}$ was found to be leaching.

\section{JLT-13 Analysis Results}

As for the JLT-13 leaching test, the results showed that the MWFA solidified with OPC stabilized all metals especially when ash to cement ratio was 50:50 and 40:60. Addition of activated carbon or rice husk reduced leaching of most of the heavy metals to below the JLT and Malaysia Environmental Quality Act 1974, Environmental Quality (Sewage and Industrial Effluents) Regulations, 1979, Standard B limits. However $\mathrm{Pb}$ concentration for the medical waste: OPC: rice husk solidified samples increased from $3.78 \%$ to $16.31 \%$ as cement loading increased.

The MSC binder for the MWFA and the addition of $\mathrm{Rh}$ inhibited leaching of all metals. Addition of activated carbon, however, reduced the immobilization efficiency and showed an increase in leaching of $\mathrm{Zn}$ between $0.267-0.34 \mathrm{mg} / \mathrm{L}, \mathrm{Pb}(0.045$ - $0.319 \mathrm{mg} / \mathrm{L})$ and $\mathrm{Cd}(0.101-0.103 \mathrm{mg} / \mathrm{L})$ as cement loading increased. The leaching concentration of $\mathrm{Cd}$ tested in the extract was below the limits of both the standards. As for MWFA when solidified with GGBS alone and with $\mathrm{Ac}$ or $\mathrm{Rh}$, managed to reduce the leaching of most metals of concern to below detection in the JLT leaching extract. The leachant from solidified ash samples showed a $\mathrm{pH}$ range between 5 and 12 (Figure 4). $\mathrm{Cr}, \mathrm{Pb}, \mathrm{Zn}, \mathrm{Cu}$ and $\mathrm{Fe}$ showed amphoteric behaviour by having higher solubility at both low (below 7) and high pH (above 11). 


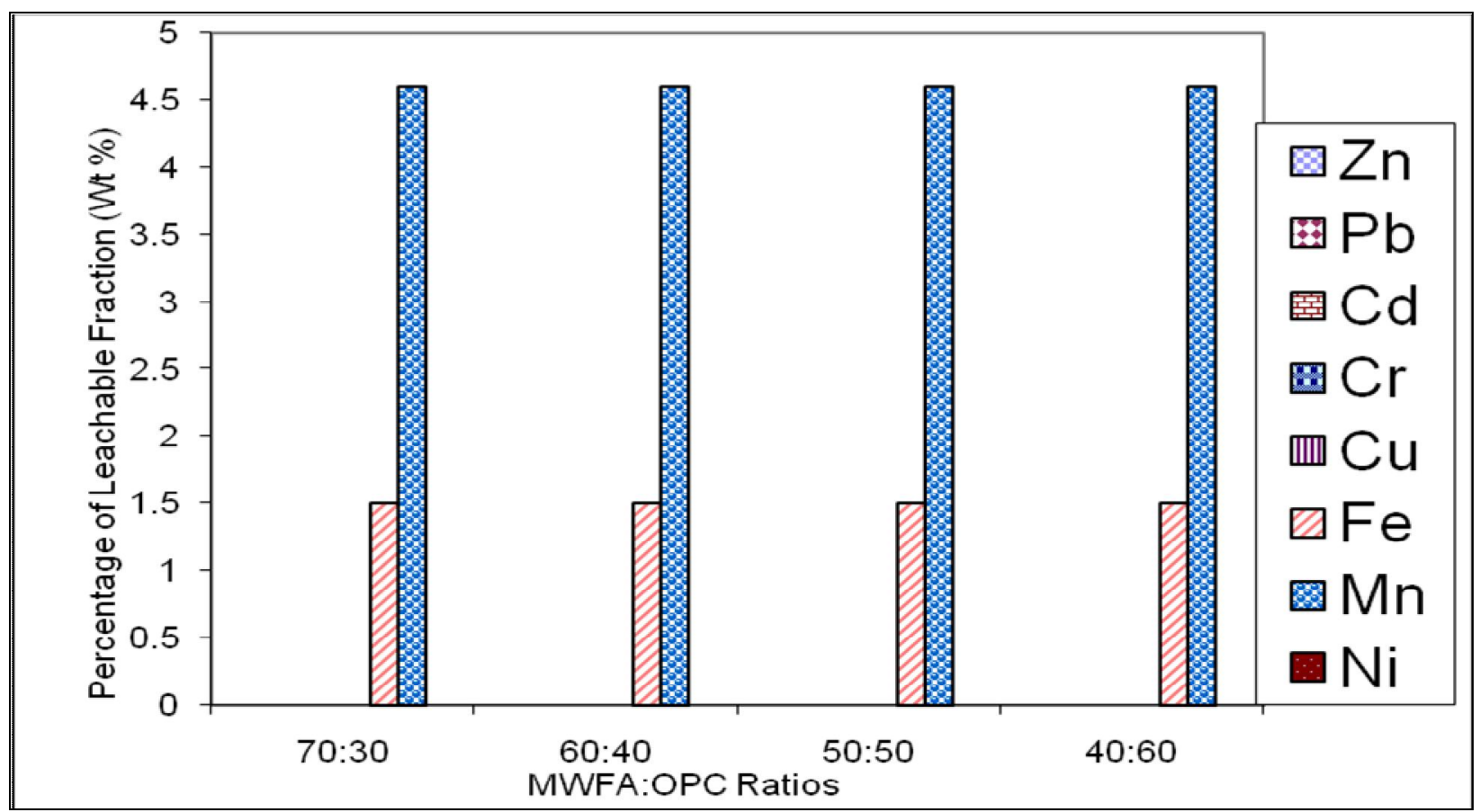

Figure 1. Percentage of leachate fraction of the heavy metals of concern in the leachate from Medical Waste (MW) ash- OPC treated samples.

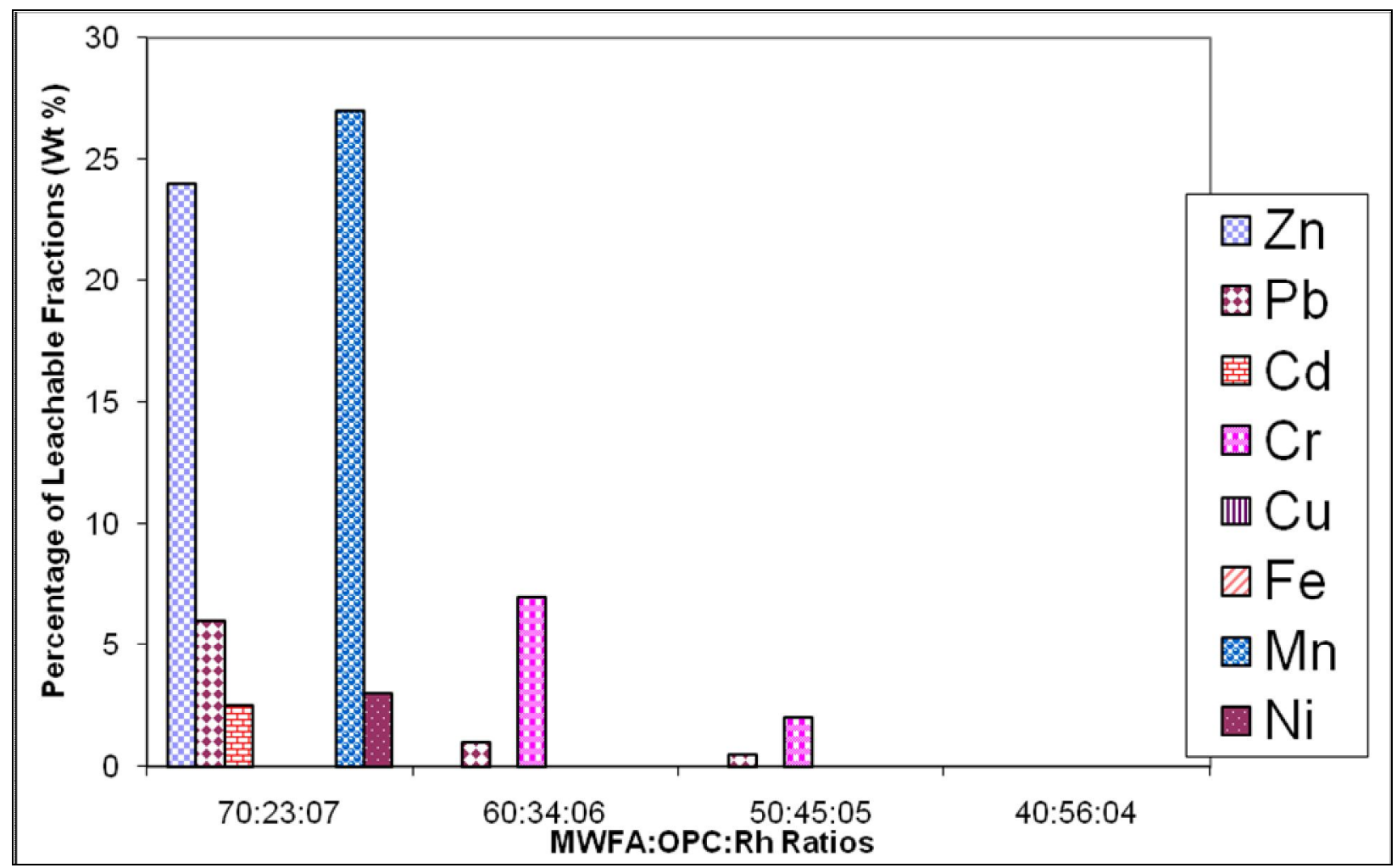

Figure 2. Percentage of leachate fraction of the heavy metals of concern in the leachate from MW ash- rice husk and OPC treated samples. 


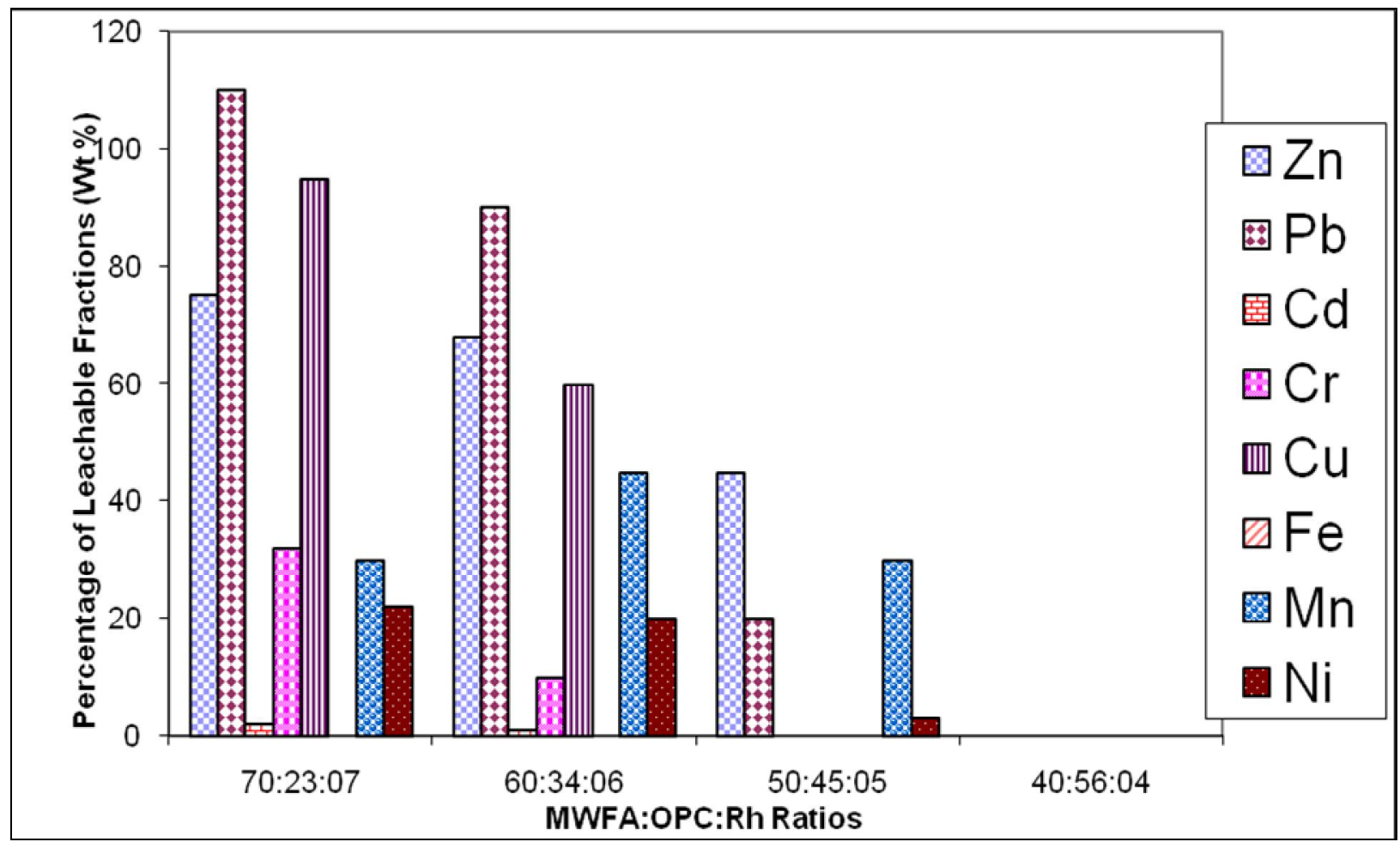

Figure 3. Percentage of leachate fraction of the heavy metals of concern in the leachate from MW ash- Activated carbon with MSC cement treated samples

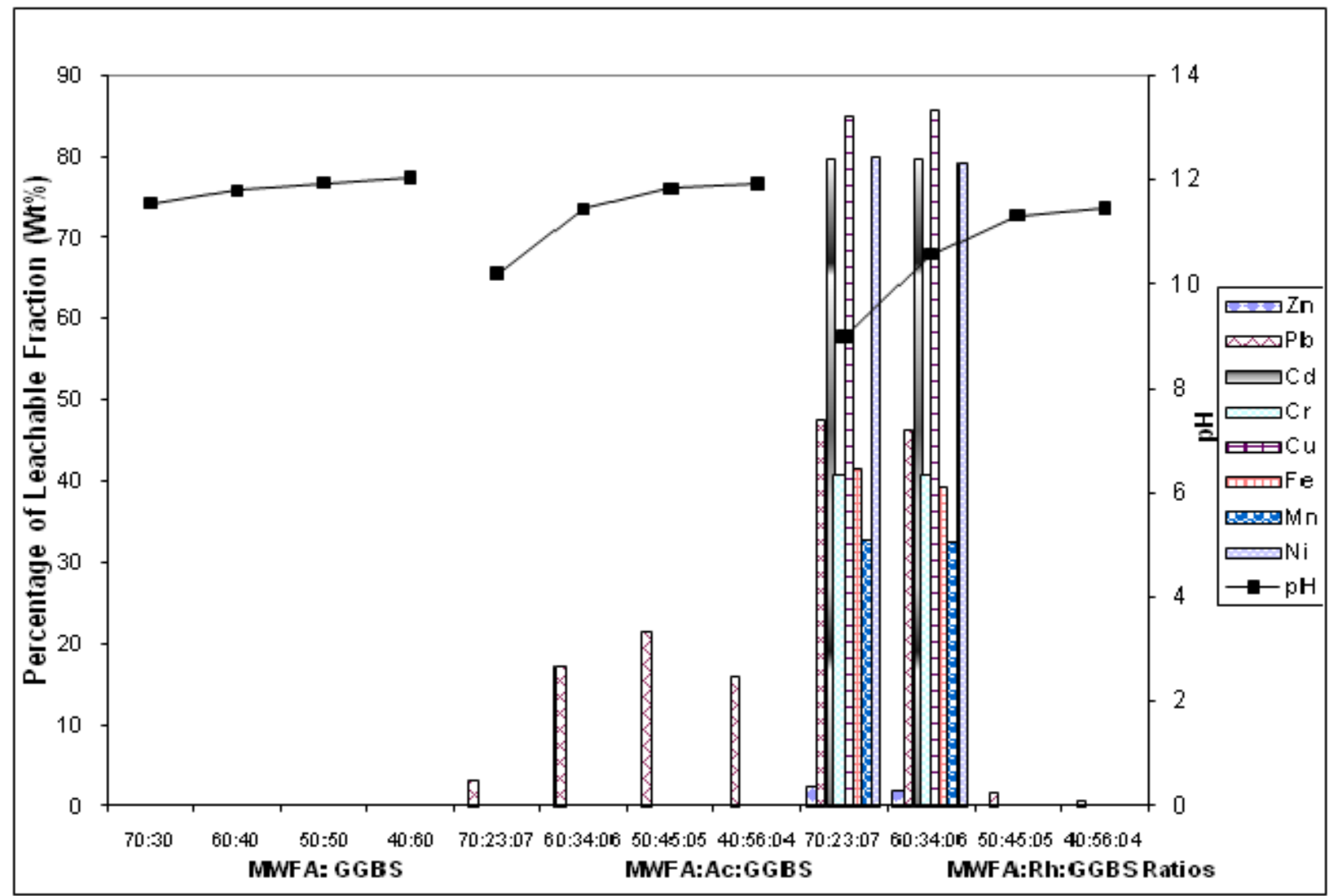

Figure 4. Percentage of Leachable Fraction and the pH changes in the JLT-13 extract of GGBS treated samples. 


\section{ANS 16.1 Analysis Results}

In general, from the results analyzed it was observed that most of the leaching rate for all the metals tested decreased as the leaching time prolonged. It was also noticeable that the leaching rate of most metals is usually higher on the first day as compared to the other intervals. This could be due to the initial surface wash off of the solidified specimens. Only two metals, $\mathrm{Cr}$ and $\mathrm{Ni}$ reduced notably for all the sets of cement loads $(70 \%, 60 \%, 50 \%$ and $40 \%)$. The leaching rate of most of the metals tested in the solidified ash with MSC showed a decreasing trend from the first day until the final test day. The leach rates of most metals reduce drastically until about the seventh day and the leach rate subsequently becomes constant (Figure 5). When the solidified MWFAGGBS waste matrix was subjected to the ANS 16.1 leach test, it was observed that the solidified matrix dissolved in the leach solution following the second day in the solution. This was observed for all the four ash loading (70\%-40\%). As such, the test was not carried out for MWFA-GGBS solidified waste matrix.

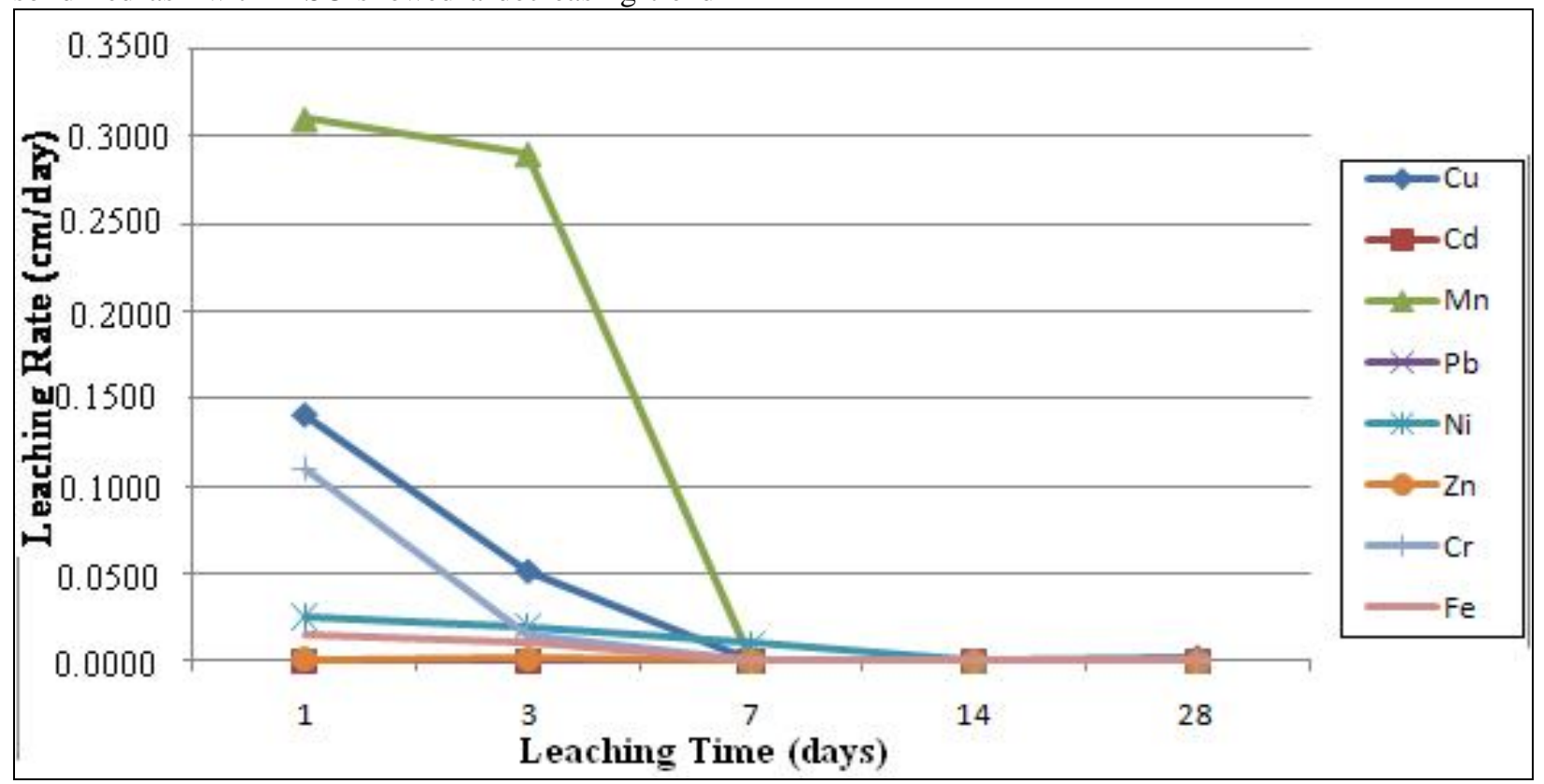

Figure 5a. Leaching Rate of The Heavy Metals of concern in MWFA-MSC Treated Samples at 70:30 ratio

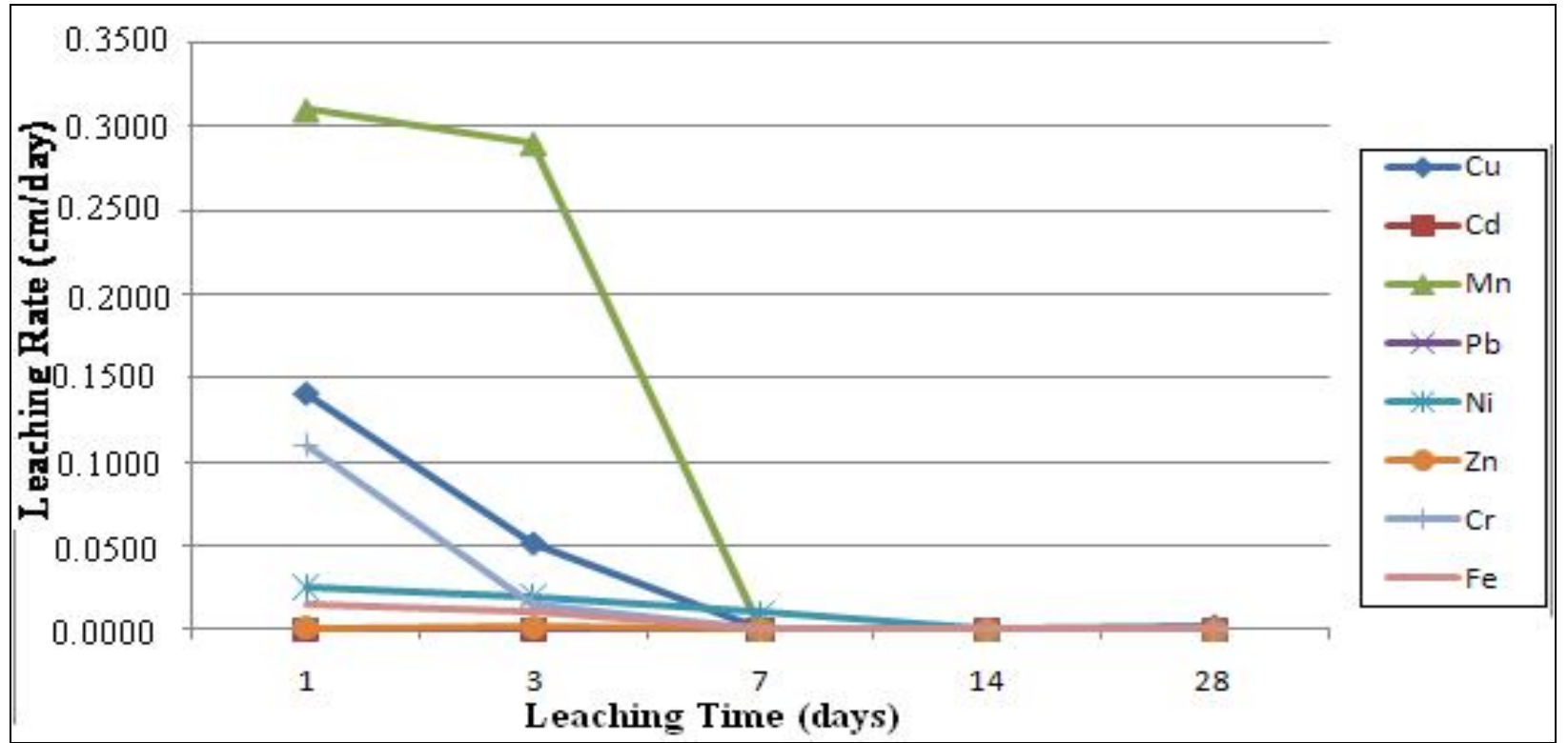

Figure 5b. Leaching Rate of The Heavy Metals of concern in MWFA-MSC Treated Samples at 60:40 ratio 


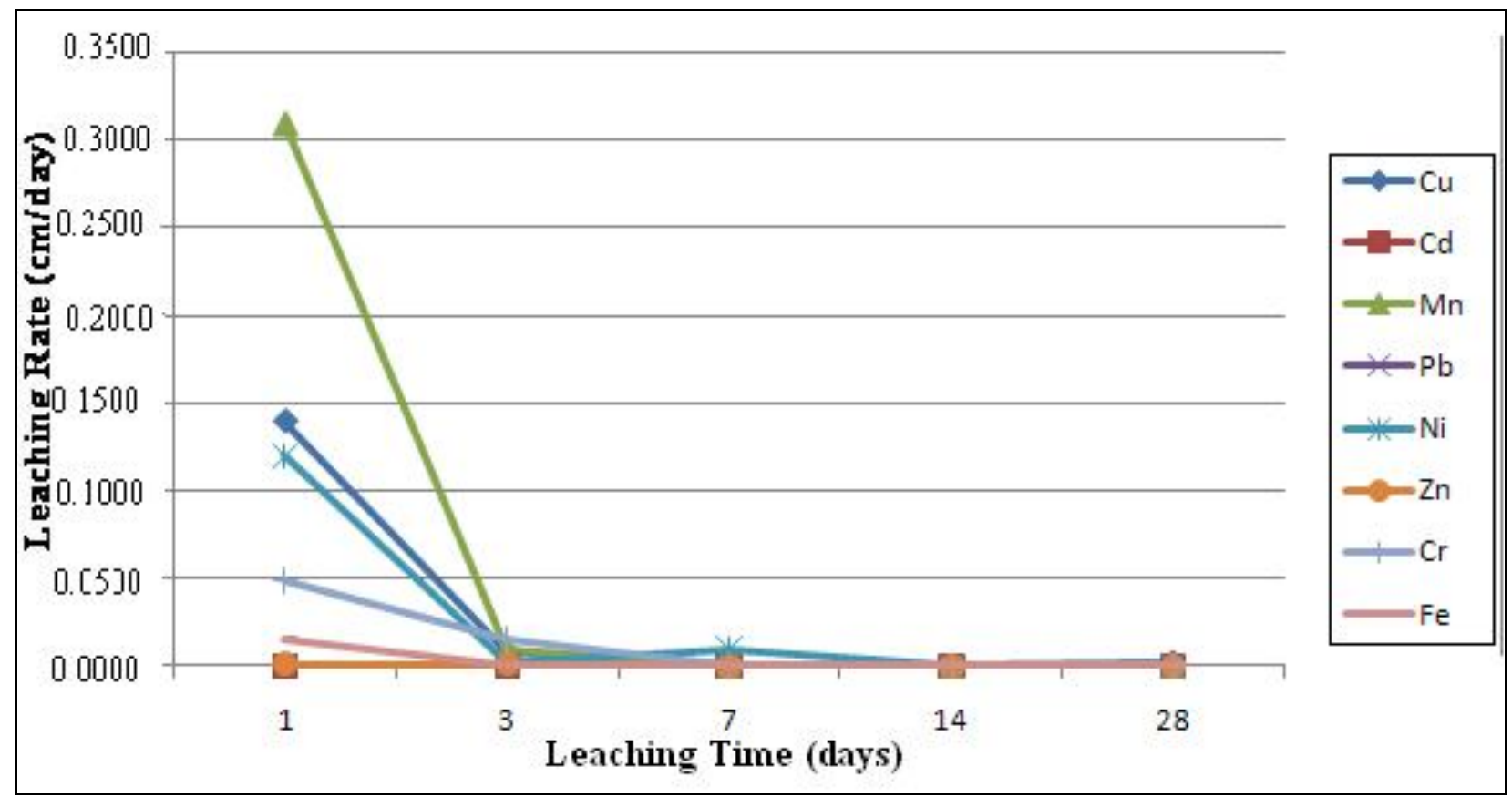

Figure 5c. Leaching Rate of the Heavy Metals of concern in MWFA-MSC Treated Samples at 50:50 ratio

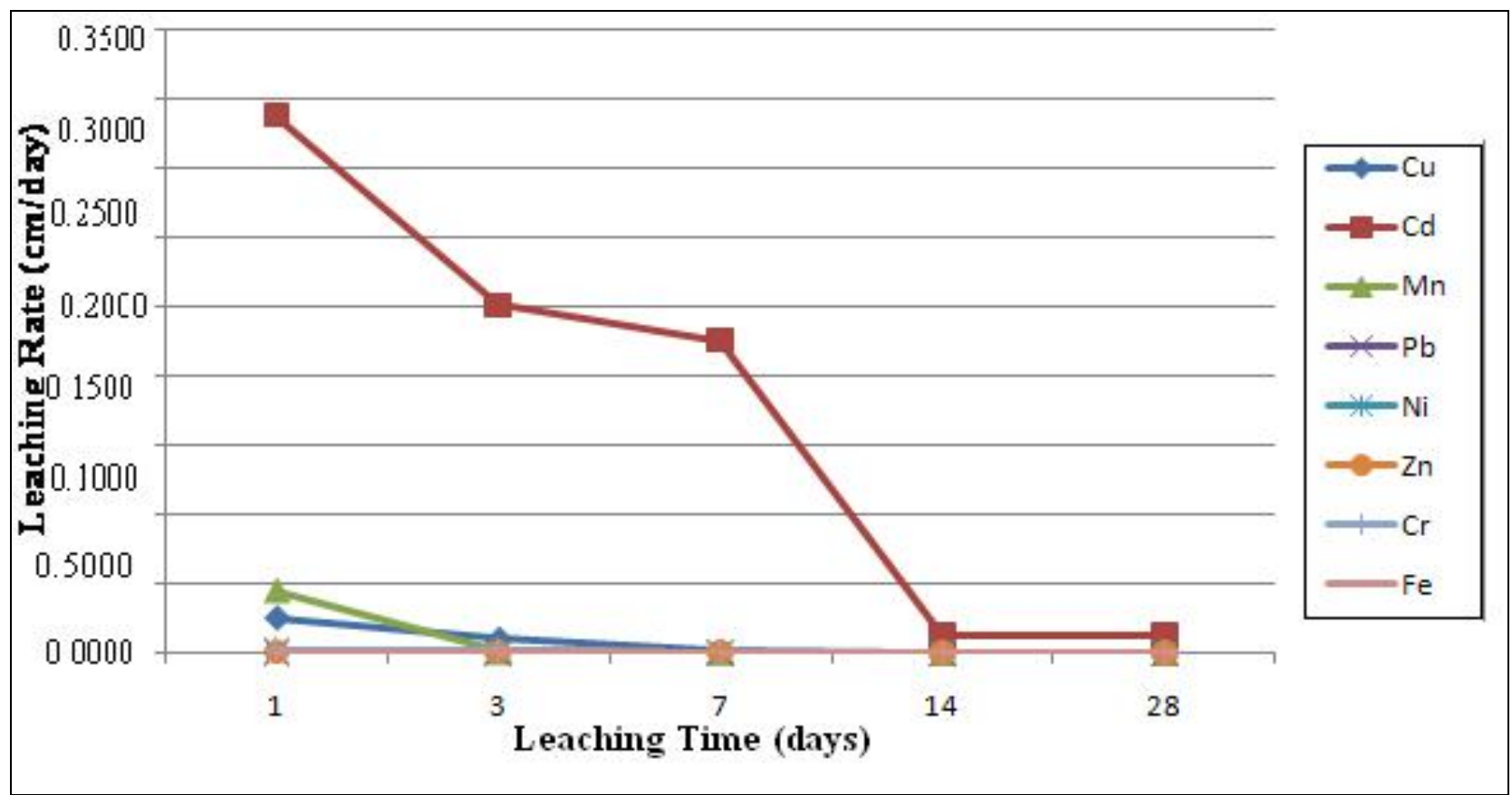

Figure 5d. Leaching Rate of The Heavy Metals of concern in MWFA-MSC Treated Samples at 40:60 ratio. 


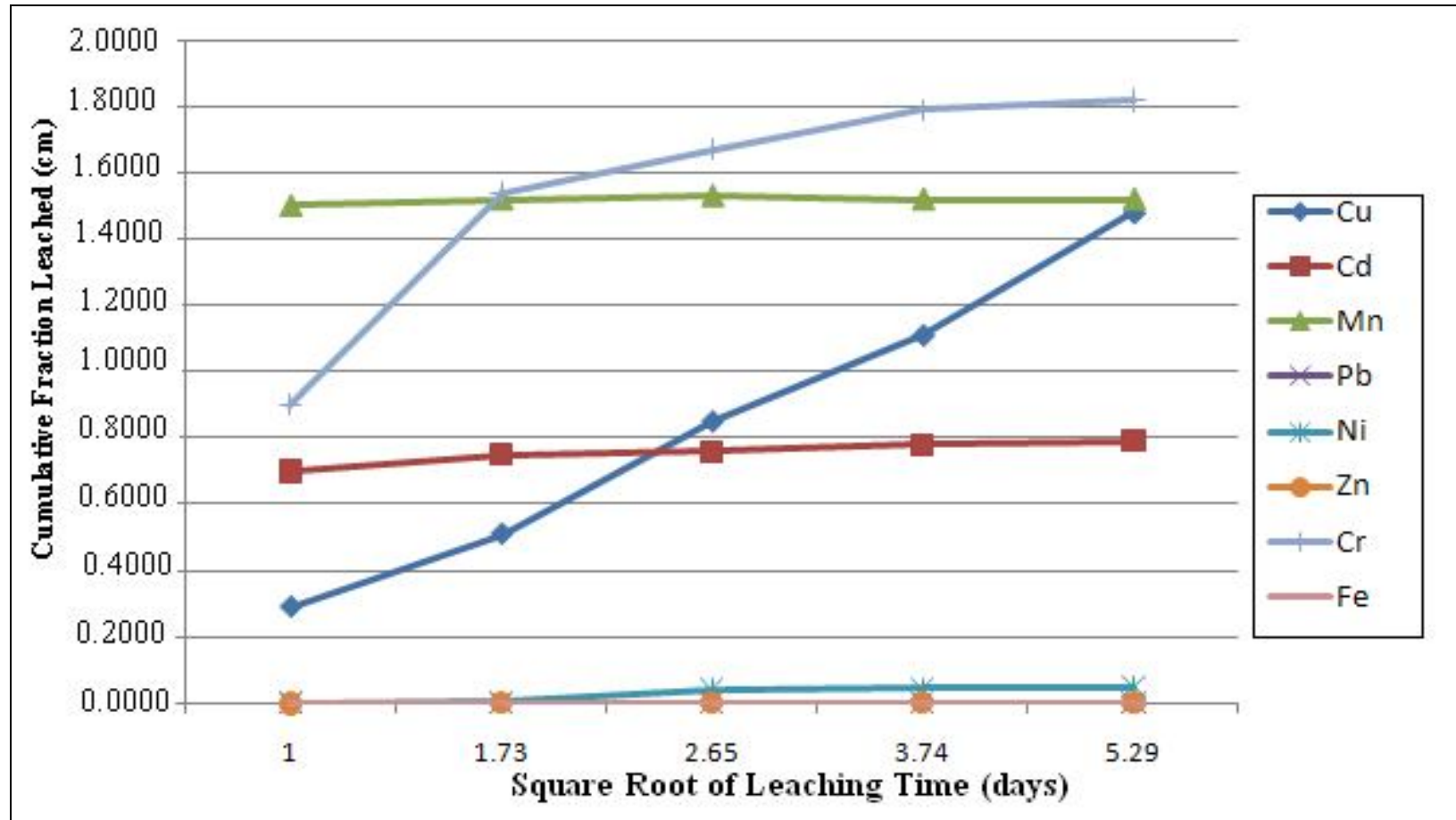

Figure 6a. Cumulative Fraction Leached for the heavy metals of concern in MWFA-OPC Treated Samples at $70: 30$ ratio

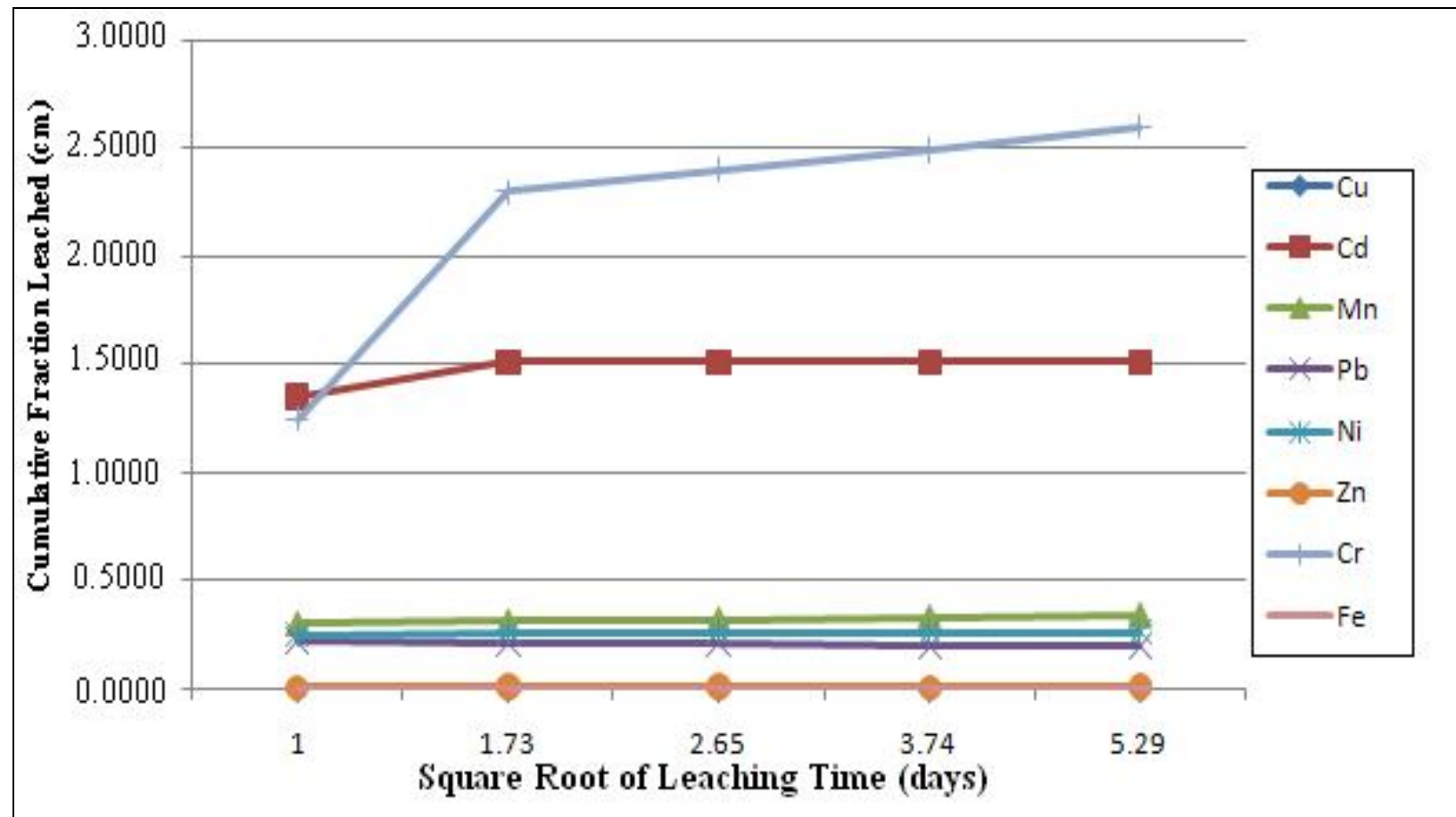

Figure 6b. Cumulative Fraction Leached for the heavy metals of concern in MWFA-OPC Treated Samples at 60:40 ratio 


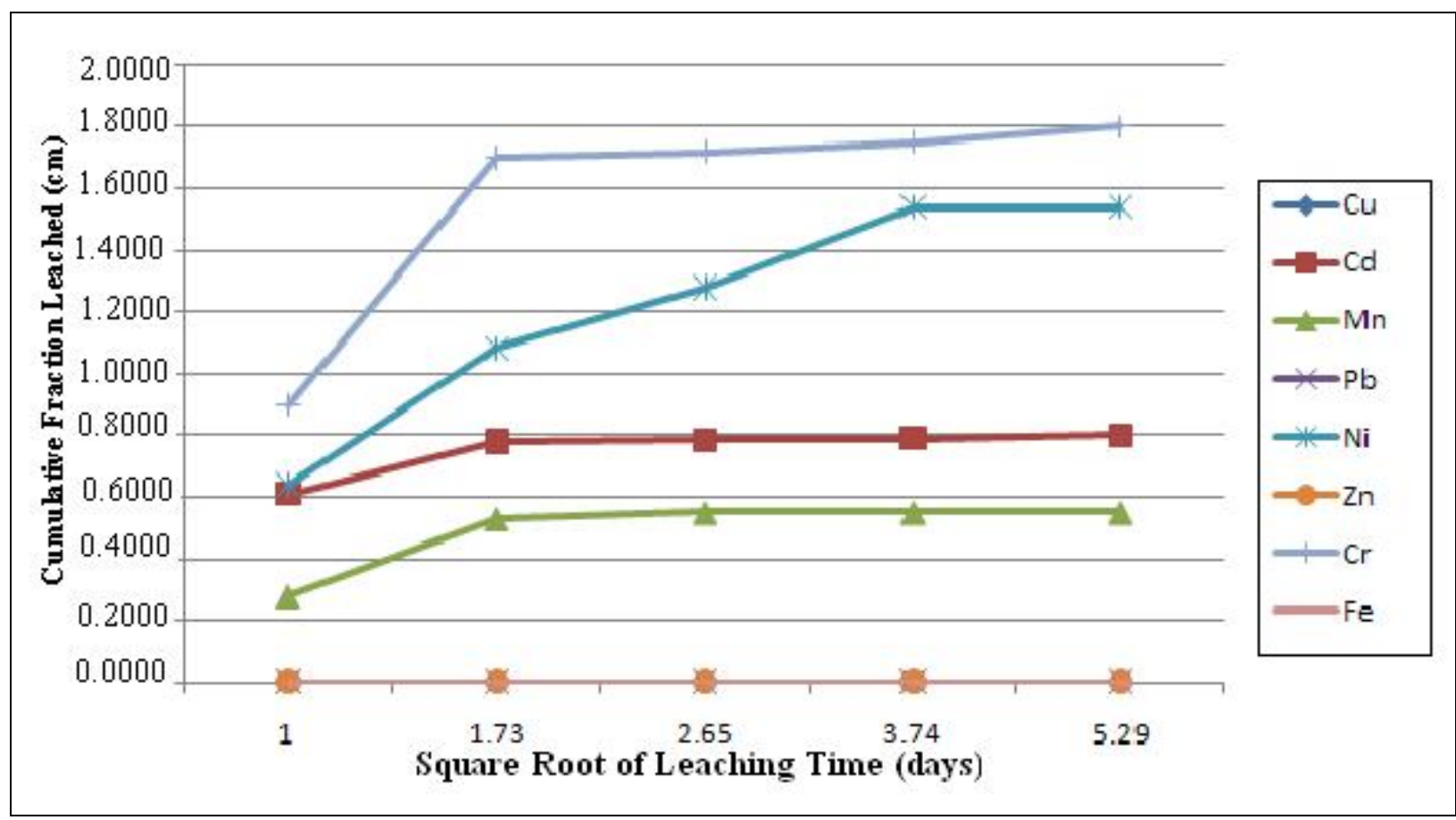

Figure 6c. Cumulative Fraction Leached for the heavy metals of concern in MWFA-OPC Treated Samples at 50:50 ratio

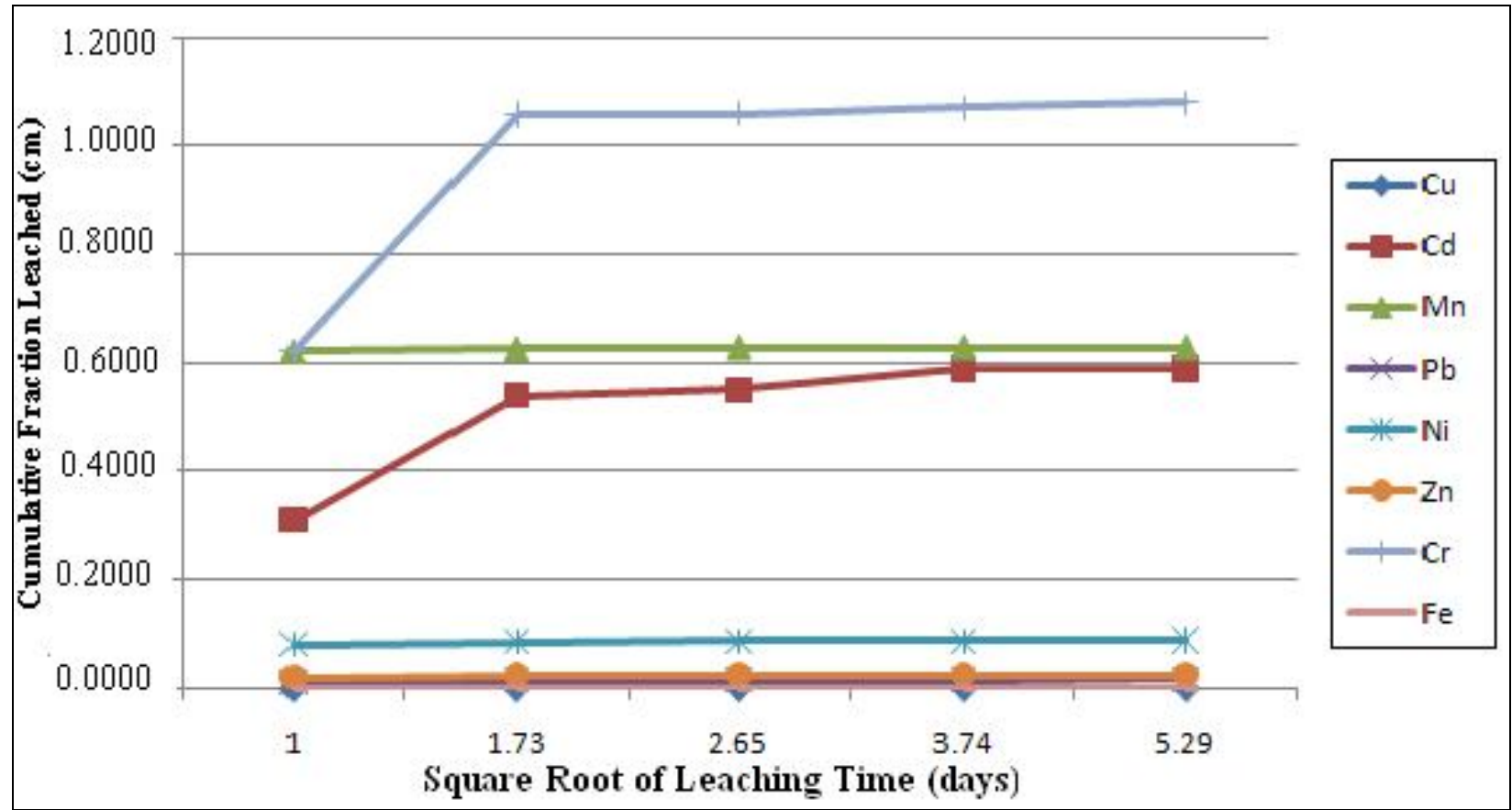

Figure 6d. Cumulative Fraction Leached for the heavy metals of concern in MWFA-OPC Treated Samples at 40:60 ratio 
The leachability index $\left(\mathrm{L}_{\mathrm{i}}\right)$ defines the ability of the metals to diffuse out of the solidified waste matrix through the leaching process. According to Morgan and Bostick (1992), if the leachability index exceeds 6 , the toxic metals are well retained in the solidified specimens. The $\mathrm{Li}$ values of the solidified MW ash when solidified with MSC were between 1.5-12.2, for MW-Ac-MSC was between 3 and 11.2 and for MW-Rh-MSC was between 3.0 - 11.6. It was observed that the Li values were higher in the $70 \%$ ash load (when solidified with MSC alone and with Ac or $\mathrm{Rh}$ ) as compared to the other ash loads (figure 7). This indicates the metals are well retained within the solidified waste form.

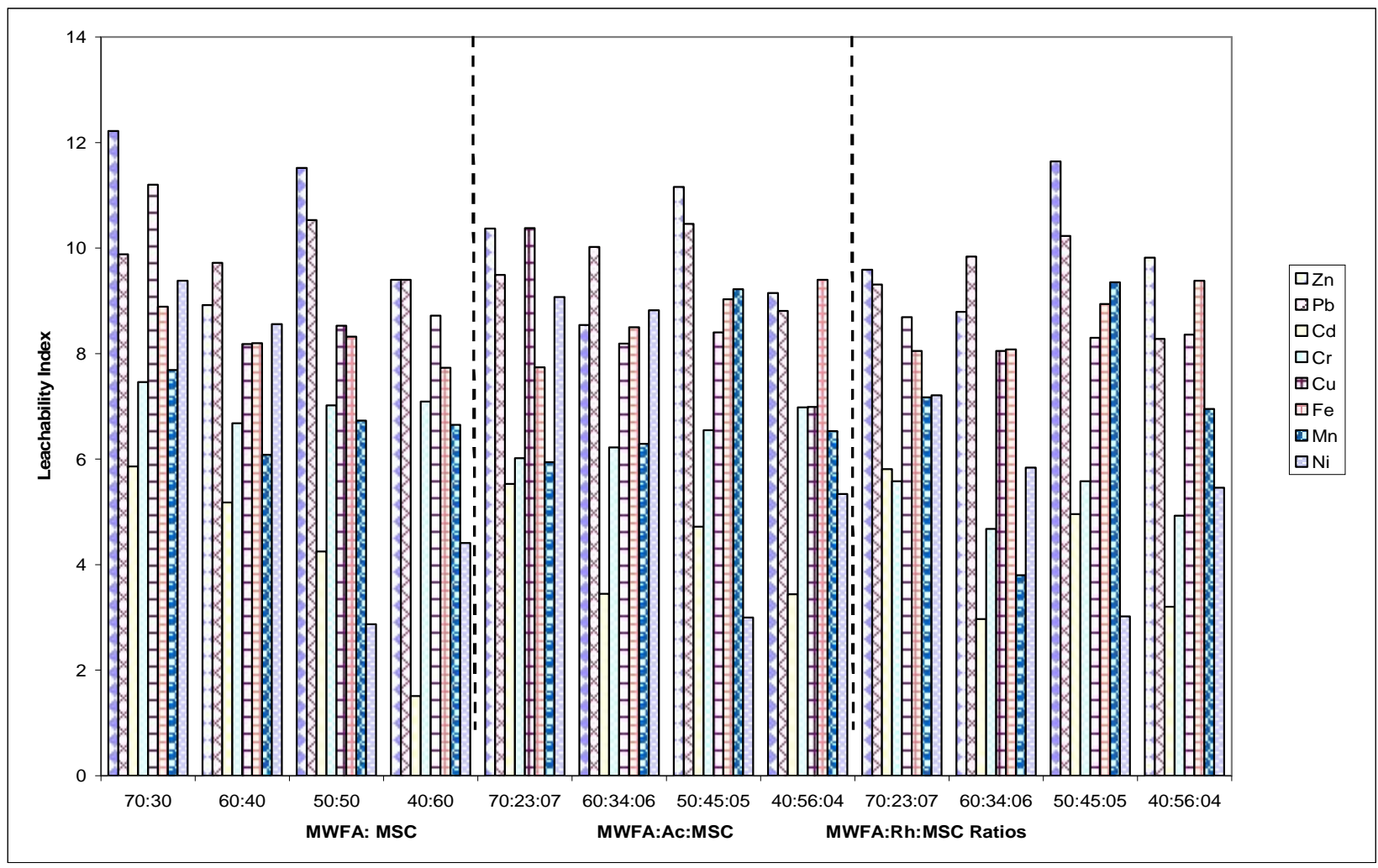

Figure 7. Leachability Index for MWFA treated with MSC and with Ac or Rh.

In the MW-MSC solidified waste, the compressive strength was between $0.6-1.8 \mathrm{MPa}$ and when Ac and $\mathrm{Rh}$ were added, the compressive strength was between 0 - 1.9 $\mathrm{MPa}$ and 0.5 - 1.9 $\mathrm{MPa}$ respectively. As for the MW-GGBS solidified waste, the compressive strength was between $0-0.7 \mathrm{MPa}$ for the MW solidified with GGBS alone and for MW-AcGGBS was between $0-0.9 \mathrm{MPa}$ and when added with $\mathrm{Rh}$ was between $0.3-0.8 \mathrm{MPa}$

\section{Physical Test Results \\ Hardening Time}

The hardening time of the medical waste ash took about 120 hours. The presence of $\mathrm{Cu}, \mathrm{Pb}$ and $\mathrm{Zn}$ compounds are set-inhibiting and could have contributed to the increase in setting time (Zain et al., 2004). The samples added with $\mathrm{Ac}$ and $\mathrm{Rh}$ took slightly longer (about 6 - 12 hours) than cement alone samples because lesser cement was available to bind the cement to the waste.

\section{Unconfined Compressive Strength Analysis}

The unconfined compressive strength was tested on the $7^{\text {th }}, 14^{\text {th }}$ and $28^{\text {th }}$ day of curing. The test was not conducted after 24 hours of mixing because most of the combined waste did not harden within this time frame; thus, the first compressive strength was only conducted after the $7^{\text {th }}$ day of compaction. MWFA showed a low compressive strength because metals such as $\mathrm{Pb}, \mathrm{Cu}$ and $\mathrm{Cr}$ could have inhibited the solidification of the matrix. It was also observed that the compressive strength of the waste matrices was higher for the OPC-treated samples (figure 8) followed by MSC-treated samples and finally by GGBS-treated samples. Overall it was observed that for samples added with Ac and Rh, the compressive strength was slightly lower than for samples solidified with cement alone. This could be because lesser cement was available to bind the metals within the solidified waste matrix. 


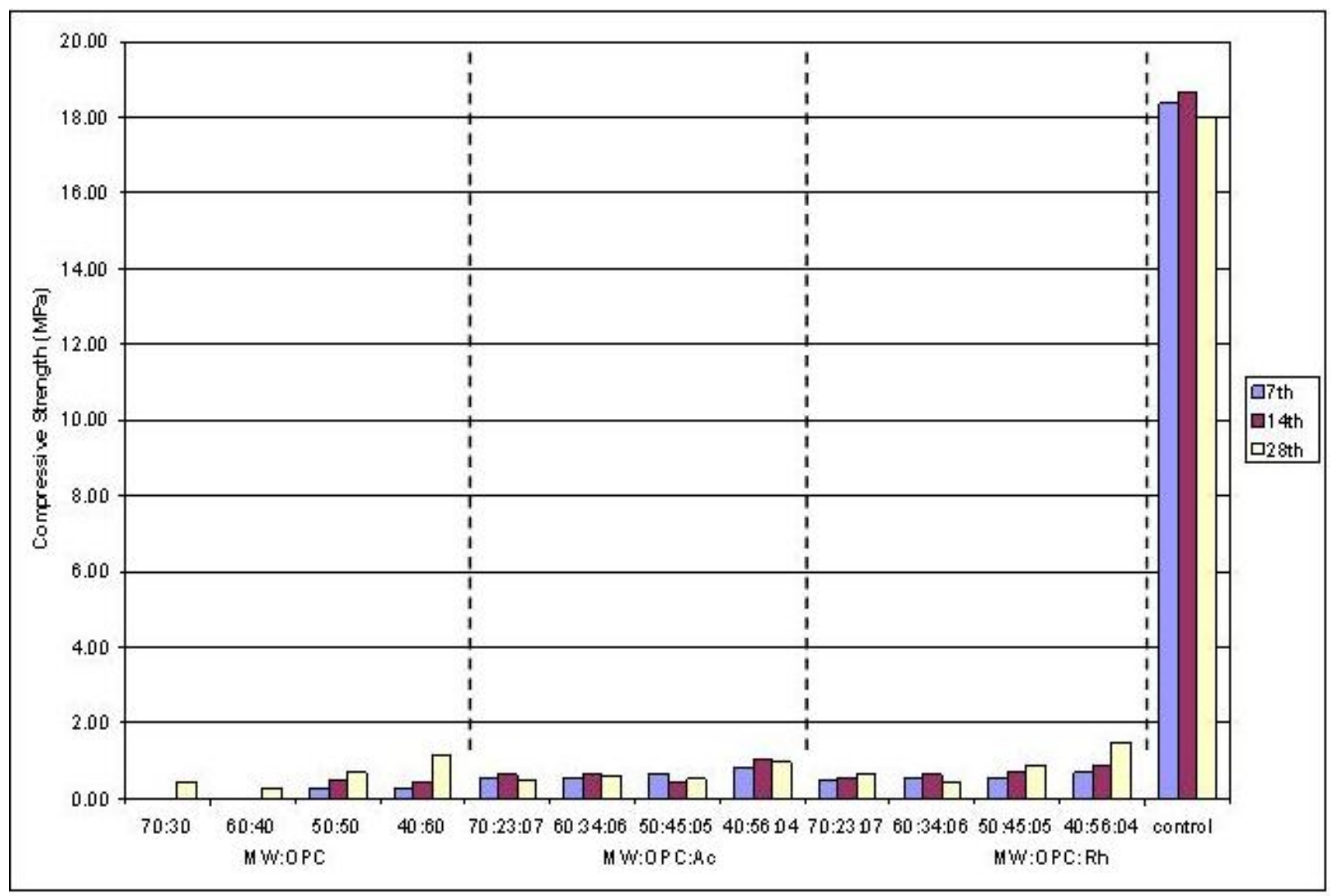

Figure 8. Unconfined Compressive Strength of MWFA after $7^{\text {th }}, 14^{\text {th }}$ and $28^{\text {th }}$ day of Solidification with OPC.

\section{CONCLUSIONS}

Based on the study the following can be concluded:

(i) Additions of activated carbon/rice husk reduced heavy metal leaching from the solidified fly ash. These are effective for the $\mathrm{S} / \mathrm{S}$ of fly ash using cement.

(ii) Increasing the percentage of cement is not effective for decreasing metal diffusibility.

(iii) Effectiveness of additives for decreasing metal diffusibility is not significant in this study.

(iv) Addition of activated carbon/rice husk decreased the unconfined compressive strength.

The solidification and stabilization treatment of ash from MW proved that our method is a good treatment option but the treatment is 3 - 5 times more costly compared to the direct landfilling of the ashes. However, the use of cement, in particular OPC, effectively reduced and bound the metals within the solidified matrix.

\section{REFERENCES}

1. Biyani, R. K., Agamuthu, P. Mahalingam, R. 2001. Polyester Resin Microencapsulation in Hazardous and Radioactive Waste Treatment Technologies Hand Book. New York: CRC Press

2. Chan, Y. M. 1999. Waste Management and Treatment in an Automobile Brake Manufacturing Facility. Master of Technology (Environmental Management) Thesis, University Malaya, Kuala Lumpur. pp. 51 - 56, 77 - 92.

3. Chan, Y. M., Agamuthu, P., Mahalingam, R. 2000. Solidification and Stabilization of Asbestos Waste from an Automobile Brake Manufacturing Facility using Cement. Journal of Hazardous Materials B77: 209 - 226.

4. Cheng, K. Y., Bishop, P. L. 1996. 'Morphology and $\mathrm{pH}$ Changes in Leached Solidified and Stabilized Waste Forms' in S/S of Hazardous, Radioactive and Mixed Wastes: $3^{\text {rd }}$ Volume. ASTM STP 1240: 73 - 78.

5. Côté, P., Gilliam, M. 1989. Environmental Aspects of Stabilization and Solidification of Hazardous and Radioactive Wastes. American Society for Testing and Materials (ASTM), USA. 
6. Department of Environment (Ministry of Science, Technology and the Environment), Malaysia 2002. Malaysia Environmental Quality Report 2001. Malaysia: Machentar Printers Sdn Bhd.

7. LaGrega, M., Buckingham, P. L., Evans, J. C. 1994. Hazardous Waste Management. USA: McGraw Hill Inc. pp. 141 - 750.

8. Lambge, L. C, Hills, C. D., Poole, A. B. 1997. Effect of Carbonation on Properties of Blended and Non-Blended Cement Solidified WaSte Forms. Journal of Hazardous Waste 52: 193 212.

9. Environmental Quality Act, Malaysia 1974 (Act 127) and Subsidiary Legislations 1999. Malaysia: International Law Book Services.

10. Means, L. J. 1995. The Application of Solidification and Stabilization to Waste Materials. USA: Lewis Publishers

11. Morgan. I. L., Bostick, W. D. 1992. Performance testing of grout-based waste forms for the solidification of anion exchange resins. In T.M. Gilliam and C.C. Wiles, Eds. Solidification/Stabilization of Hazardous, Radioactive and Mixed Wastes, ASTM STP 1123. Philadelphia, P.A: American Society for Testing and Materials: $133-145$.

12. Pojasek, B. R. 1979. Toxic and Hazardous Waste Disposal Volume 1: Processes for Stabilization/ Solidification, USA: Ann Arbor Science Publishers Inc.

13. Rhyner, R. C., Schwartz, J. L. Wenger, B. R., Kohrell, G. M. 1995. Waste Management and Resource Recovery. USA: CRC Press. pp. 241 268, 273 - 301.

14. Roy, A., Eaton, H. C. 1992. S/S of a Synthetic Electroplating Waste in Lime-fly Ash Binder. Cement and Concrete Research 22: 589 - 596.

15. Shively, W. B., Bishop, P. T., Gress, D. 1992. Heavy Metal Binding Mechanism in the S/S Hazardous Waste Treatment Process. pp. 268 278.

16. Van der Sloot, H. A., de Groot, G. J., Wijkstra, J. 1989. Leaching Characteristics of Construction Materials and Stabilization Products Containing Waste Materials in Environmental Aspects of S/S of Hazardous Waste and Radioactive Waste, ASTM STP 1033. pp. 125 - 149.

17. Wiles, C. C. 1987. A Review of Solidification and Stabilization Technology. Journal of Hazardous Materials 14: 5 - 21.

18. Zain, M. F. M., Islam, M. N., Radin, S. S., Yap, S. G. 2004. Cement-based Solidification for the Safe Diposal of Blasted Copper Slag. Cement and Concrete Composites 26 (7): 845 - 851.
19. Zamorani, E. 1994. Environmental Management, in A. Avogadro, R. C. Ragini (Eds.), Technologies for Environmental Cleanup: Toxic and Hazardous Waste Management (Vol. 2). p. 177.

20. United States Environmental Protection Agency 1989. Stabilization / Solidification of CERCLA and RCRA Wastes. USA: United States Environmental Protection Agency. 
Malaysian Journal of Science 28 (3): 241- 255 (2009) 